\title{
ATTITUDES OF 15-16-YEAR-OLD PUPILS WITH A SUFFICIENT ACTIVITY LEVEL TOWARDS THE PHYSICAL EDUCATION TEACHER AND THEIR BEHAVIOUR
}

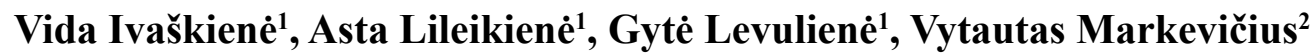 \\ Lithuanian Sports University ${ }^{l}$, Kaunas, Lithuania, \\ Mykolas Romeris University', Vilnius, Lithuania
}

\begin{abstract}
Background. As our society is subject to changes, knowledge about the learners' attitudes towards a physical education teacher, their behaviour and characteristics can help to more effectively address the problems of physical education at school. The research hypothesis was raised in this article as follows: attitudes of 15-16-year-old pupils with a sufficient activity level towards a physical education teacher and their behaviour will differ with respect to gender: the male pupils' approach will be more positive than that of female pupils. Research aim was to investigate the attitudes of 15-16-year-old pupils with a sufficient activity level towards a physical education teacher and their behaviour.

Methods. The survey was conducted during physical education classes in Kaunas secondary schools in spring, 2015. The questionnaire survey was carried out. Questionnaire data of 300 sufficiently physically active pupils (150 boys and 150 girls) were analysed.

Results. Both boys and girls indicated good knowledge of the subject, friendliness, communication with the group, taking into account pupils' opinions as the most appealing characteristics of the physical education teacher. Both genders considered that the most unfavourable teacher characteristics were insisting on meeting physical standards, non-involvement in physical activities together with pupils in the classroom and disregarding pupils' needs and wishes. More girls than boys $(p<.05)$ did not appreciate the teacher's non-communication with pupils, lack of dedication and making offensive comments.

Conclusions. Both boys and girls pointed out that the most appealing traits of the physical education teacher's characteristics were good knowledge of the subject, friendliness, communication with the group and taking into account pupils' opinions. Girls appeared to be more demanding to the physical education teacher's behaviour than boys.
\end{abstract}

Keywords: attitude to physical education teacher, pupils, teacher's behaviour.

\section{INTRODUCTION}

$\mathrm{P}$ hysical education (PE) teacher is the most important person at school who should not only aim to meet pupils' need for activity, improve their physical fitness but also develop the competencies of physical education in the field, promote a positive attitude towards physical activity and physical self-development (Emeljanovas \& Trinkūnienè, 2011; Hardman, 2008; Jaakkola \& Washington, 2013; Van den Berghe et al., 2014).
Scientists claim that pupils are educated physically effectively when they experience positive emotions, joy, happiness during physical education lessons, as these factors in particular induce the need for physical activity, increase the desire to play sports and socialize (Blauzdys \& Vilkas, 2007). Fominienè, Kardelienè, and Kardelis (2006), Petrylaitè and Emeljanovas (2012) argue that a pleasant surprise is important in the 
PE lesson. Physical education teachers have a possibility to influence each individual learner, apply the alternative forms of teaching and achieve quick and significant results, etc. (Atencio, Jess, \& Dewar, 2012; Blauzdys \& Vilkas, 2007; Freire \& Miranda, 2014; Juškelienė, Poteliūnienė, Gudžinskienė, \& Blauzdys, 2010; Poteliūnienè, Blauzdys, \& Juškelienè, 2012).

Scientific research is more focused on the PE teacher's perception of health education and competence at school (Juškelienė et al., 2010), professional challenges in the physical education teacher's work (Trinkūnienè \& Kardelienè, 2013; Trinkūniene, 2015), the PE teacher's opinion about the learners' personal traits (Kardeliene, Trinkūnienè, Kardelis, \& Masiliauskas, 2013), pupils' progress and achievement assessment during physical education classes (Emeljanovas \&Trinkūnienè, 2011; Van den Berghe et al., 2014), teachers' readiness to apply the new ideas for pupils' physical education (Atencio et al., 2012; Poteliūnienè et al., 2012; Jaakkola \& Washington, 2013; Trinkūnienè, 2015).

Understanding and communication between the teacher and the pupil take place simultaneously (Freire \& Miranda, 2014; McDavid, Cox, \& McDonough, 2014; Van den Berghe et al., 2014). The PE teacher's personality, features of interaction with pupils, ability to motivate pupils to be physically active, exercise lead to pupils' positive attitudes to physical education, create the need to be physically active in their further lives (Atencio et al., 2012; Bernstein, Phillips, \& Silverman, 2011; Jaakkola \& Washington, 2013; McDavid et al., 2014).

We believe that as our society is subject to changes, knowledge about the learners' attitudes towards the physical education teacher, their behaviour and characteristics can help to more effectively address the problems of physical education at school, thus research in this area is meaningful and relevant.

Hypothesis: attitudes of 15-16-year-old pupils with a sufficient activity level towards the physical education teacher and their behaviour will differ with respect to gender: the male pupils' approach will be more positive than that of female pupils.

Research aim was to investigate the attitudes of 15-16-year-old pupils with a sufficient activity level towards physical education teacher and their behaviour.

\section{METHODS}

Research methods: 1) analysis and discussion of scientific literature; 2) questionnaire survey; 3) statistical analysis. Anonymous questionnaire survey was conducted during physical education lessons in Kaunas secondary schools in spring, 2015. Questionnaire data of 300 pupils (150 boys and 150 girls) were analysed. According to the responses to the IPAQ International Questionnaire (http://ipaq.ki.se/downloads.htm) they were determined as sufficiently physically active.

The research data were analysed using the statistical data software package SPSS 17.0 for Windows. Chi-square test $\left(\chi^{2}\right)$ was used to evaluate statistical differences between the groups. The significance level of hypotheses' conclusions was set at $p<.05$, statistically non-significant - at $p>.05$. Internal consistency of the scales was evaluated according to Cronbach's alpha coefficient (.79).

\section{RESULTS}

The analysis of pupils' responses about the most appealing physical education teacher characteristics established that there was no significant difference in replies to the given statements between boys and girls $(p>.05)$ (Table 1). Both boys and girls appreciated the PE teacher's knowledge of their study course: answer options strongly agree and agree were noted by $90 \%$ of boys and $89.3 \%$ of girls. They liked friendliness of PE teacher very much as well (answer options strongly agree and agree were noted by 89.3 and $89.4 \%$ of the respondents respectively), interaction with a group (86.7 and $90 \%$ of the respondents respectively); they emphasized that the physical education teacher was easy to communicate with ( $84 \%$ and $80 \%$ of the respondents respectively) (Table 1).

It was determined that pupils liked the fact that physical education teacher took into account pupils' opinions, was calm, creative, applied innovations, was interested in each pupil, had a sense of humour and a good physical appearance - answer options strongly agree and agree were noted by more than half of the respondents (Table 1).

The analysis of pupils' responses about the least appealing physical education teacher characteristics demonstrated (Table 2) that both boys and girls did not like the same traits of physical education teacher. Most pupils did not appreciate when the teacher 
Table 1. Percentage distribution of responses to the question "What traits of the PE teacher characteristics do you like?"

\begin{tabular}{|c|c|c|c|c|c|c|c|c|c|c|c|}
\hline \multirow[t]{2}{*}{ Statements } & \multicolumn{2}{|c|}{$\begin{array}{c}\text { Strongly } \\
\text { agree }\end{array}$} & \multicolumn{2}{|c|}{ Agree } & \multicolumn{2}{|c|}{$\begin{array}{c}\text { Neither agree } \\
\text { nor disagree }\end{array}$} & \multicolumn{2}{|c|}{ Disagree } & \multicolumn{2}{|c|}{$\begin{array}{l}\text { Strongly } \\
\text { disagree }\end{array}$} & \multirow{2}{*}{$\begin{array}{l}\chi^{2} \text { and } p \\
\text { values }\end{array}$} \\
\hline & $\mathbf{M}$ & $\mathbf{F}$ & $\mathbf{M}$ & $\mathbf{F}$ & $\mathbf{M}$ & $\mathbf{F}$ & $\mathbf{M}$ & $\mathbf{F}$ & $\mathbf{M}$ & $\mathbf{F}$ & \\
\hline Good physical appearance & 30.0 & 32.7 & 29.3 & 31.3 & 28.7 & 26.0 & 5.3 & 7.3 & 4.7 & 0.7 & $\begin{array}{l}\chi^{2}=5.438 \\
p=.365\end{array}$ \\
\hline Friendly & 39.3 & 48.7 & 50.0 & 40.7 & 6.7 & 6.7 & 2.0 & 2.7 & 1.3 & 1.3 & $\begin{array}{l}\chi^{2}=4.069 \\
p=.540\end{array}$ \\
\hline Good knowledge of the subject & 42.7 & 49.3 & 47.3 & 40.0 & 10.0 & 9.3 & 0 & 1.3 & 0 & 0 & $\chi^{2} p=.298$ \\
\hline Calm & 30.7 & 33.3 & 40.7 & 44.0 & 22.0 & 18.0 & 3.3 & 2.7 & 3.3 & 1.3 & $\begin{array}{l}\chi^{2}=3.360 \\
p=.645\end{array}$ \\
\hline Interaction with the group & 38.7 & 44.0 & 48.0 & 46.0 & 12.0 & 6.7 & 1.3 & 2.7 & 0 & 0 & $\begin{array}{l}\chi^{2}=4.532 \\
p=.339\end{array}$ \\
\hline Has a sense of humour & 34.0 & 30.0 & 41.3 & 46.0 & 20.0 & 18.7 & 1.3 & 4.0 & 2.0 & 1.3 & $\begin{array}{l}\chi^{2}=5.018 \\
p=.414\end{array}$ \\
\hline Interested in each pupil & 30.0 & 25.3 & 52.7 & 44.7 & 12.0 & 19.3 & 4.0 & 8.0 & 0.7 & 2.7 & $\begin{array}{l}\chi^{2}=8.951 \\
p=.111\end{array}$ \\
\hline Easy to communicate with & 38.0 & 37.3 & 46.0 & 42.7 & 12.7 & 15.3 & 2.0 & 0.7 & 1.3 & 4.0 & $\begin{array}{l}\chi^{2}=3.578 \\
p=.466\end{array}$ \\
\hline Creative & 24.7 & 30.7 & 40.0 & 34.0 & 25.3 & 30.7 & 6.7 & 3.3 & 3.3 & 1.3 & $\begin{array}{l}\chi^{2}=5.420 \\
p=.247\end{array}$ \\
\hline Applies novelties & 32.0 & 26.0 & 23.3 & 30.0 & 34.7 & 27.3 & 5.3 & 9.3 & 4.7 & 7.3 & $\begin{array}{l}\chi^{2}=6.007 \\
p=.199\end{array}$ \\
\hline $\begin{array}{l}\text { Considers pupils' opinions while } \\
\text { giving the tasks }\end{array}$ & 38.7 & 31.3 & 36.7 & 35.3 & 16.7 & 15.3 & 4.7 & 8.0 & 3.3 & 10.0 & $\begin{array}{l}\chi^{2}=7.589 \\
p=.108\end{array}$ \\
\hline
\end{tabular}

Note. $\mathrm{M}$ - males, $\mathrm{F}$ - females in all tables.

required to meet the physical standards (answer options strongly agree and agree were noted by $26 \%$ of boys and $32 \%$ of girls) when the teacher did not participate in physical activities with pupils in the classroom (respectively 21.3 and $27.4 \%$ of the respondents) when they did not take into account pupils' wishes and preferences (respectively 12.6 and $37.4 \%$ of the respondents). There was no significant difference found between male and female responses $(p>.05)$, but the responses to some statements differed with respect to gender.

More girls than boys $(p<.05)$ did not like that physical education teachers did not communicate with pupils (answer options strongly agree and agree were noted by $12 \%$ of boys and $19.3 \%$ of girls), when teachers lacked dedication (respectively 10 and $18.7 \%$ of the respondents), teachers were not objective to pupils (10.7 and $14.7 \%$ of the respondents), when physical education lessons were not interesting (respectively 12 and $24 \%$ of the respondents), physical education teachers made offensive remarks in the class (respectively 10.7 and $14.7 \%$ of the respondents) (Table 2).

Analysing the statement "You are performing an exercise well, the PE teacher..." it was determined that (Table 3) the teacher often praised pupils (as indicated by $50 \%$ of boys and $42.7 \%$ of girls, $p>.05$ ); that the teacher often served as an example to others (respectively 35.3 and $23.33 \%$ of the respondents, $p<.05$ ). About the tenth of the subjects identified that physical education teacher did not often pay attention to the fact that pupils were performing an exercise well.

Analysing the statement "When you did not succeed to perform an exercise well, your PE teacher..." it was determined (Table 4) that the teacher often gave advice how to perform an exercise correctly (as indicated by $64.7 \%$ of boys and $70 \%$ of girls, $p>.05$ ); a small number of pupils indicated that the teacher often mocked them (respectively 4 and $5.3 \%$ of the respondents, $p>.05$ ), ridiculed pupils (respectively 4 and $2.7 \%$ of the respondents, $p>.05$ ). The statistically significant difference was established in one aspect - more boys than girls were shouted at $(p>.05)$.

Analysing the statement "You contradict willing to defend your wishes, the PE teacher..." it was identified (Table 5) that the teacher often changed the task, as indicated by $30 \%$ of boys and $10 \%$ of girls. A relatively small number of male subjects 
Table 2. Percentage distribution of responses to the question "What traits of the PE teacher characteristics do you dislike"

\begin{tabular}{|c|c|c|c|c|c|c|c|c|c|c|c|}
\hline \multirow[t]{2}{*}{ Statements } & \multicolumn{2}{|c|}{ Strongly agree } & \multicolumn{2}{|c|}{ Agree } & \multicolumn{2}{|c|}{$\begin{array}{c}\text { Neither agree } \\
\text { nor disagree }\end{array}$} & \multicolumn{2}{|c|}{ Disagree } & \multicolumn{2}{|c|}{$\begin{array}{l}\text { Strongly } \\
\text { disagree }\end{array}$} & \multirow{2}{*}{$\begin{array}{l}\chi^{2} \text { and } p \\
\text { values }\end{array}$} \\
\hline & $\mathbf{M}$ & $\mathbf{F}$ & M & $\mathbf{F}$ & $\mathbf{M}$ & $\mathbf{F}$ & M & $\mathbf{F}$ & M & $\mathbf{F}$ & \\
\hline $\begin{array}{l}\text { Does not communicate } \\
\text { with pupils }\end{array}$ & 6.7 & 7.3 & 5.3 & 12.0 & 25.3 & 10.7 & 32.7 & 38.0 & 28.0 & 32.0 & $\begin{array}{l}\chi^{2}=16.861 \\
p=.005\end{array}$ \\
\hline $\begin{array}{l}\text { Asks to meet physical } \\
\text { standards }\end{array}$ & 6.7 & 8.0 & 19.3 & 24.0 & 26.7 & 24.0 & 27.3 & 26.7 & 20.0 & 17.3 & $\begin{array}{l}\chi^{2}=1.444 \\
p=.836\end{array}$ \\
\hline $\begin{array}{l}\text { Not involved in physical } \\
\text { activities with pupils }\end{array}$ & 5.3 & 10.7 & 16.0 & 16.7 & 28.7 & 27.3 & 26.7 & 20.0 & 23.3 & 25.3 & $\begin{array}{l}\chi^{2}=4.287 \\
p=.369\end{array}$ \\
\hline Makes offensive remarks & 8.0 & 6.7 & 2.7 & 8.0 & 16.7 & 6.0 & 36.0 & 32.0 & 36.7 & 47.3 & $\begin{array}{l}\chi^{2}=14.096 \\
p=.007\end{array}$ \\
\hline $\begin{array}{l}\text { Does not show } \\
\text { enthusiasm }\end{array}$ & 5.3 & 5.3 & 6.7 & 9.3 & 27.3 & 21.3 & 32.7 & 31.3 & 28.0 & 32.7 & $\begin{array}{l}\chi^{2}=2.356 \\
p=.671\end{array}$ \\
\hline Impatient & 4.0 & 4.7 & 6.7 & 11.3 & 24.7 & 18.7 & 30.7 & 29.3 & 31.3 & 35.3 & $\begin{array}{l}\chi^{2}=5.342 \\
p=.376\end{array}$ \\
\hline Lacks dedication & 4.0 & 8.0 & 6.0 & 10.7 & 32.7 & 17.3 & 28.0 & 32.7 & 29.3 & 31.3 & $\begin{array}{l}\chi^{2}=11.651 \\
p=.020\end{array}$ \\
\hline Not objective to pupils & 4.0 & 6.0 & 6.7 & 8.7 & 34.7 & 18.0 & 26.7 & 32.0 & 28.0 & 34.7 & $\begin{array}{l}\chi^{2}=11.694 \\
p=.039\end{array}$ \\
\hline Non-interesting activities & 8.7 & 11.3 & 3.3 & 12.7 & 26.0 & 20.7 & 24.7 & 27.3 & 36.7 & 28.0 & $\begin{array}{l}\chi^{2}=12.562 \\
p=.028\end{array}$ \\
\hline $\begin{array}{l}\text { Does not pay attention to } \\
\text { pupils' wishes }\end{array}$ & 6.0 & 12.7 & 6.7 & 24.7 & 25.3 & 44.7 & 30.7 & 14.0 & 30.7 & 4.0 & $\begin{array}{l}\chi^{2}=8.781 \\
p=.118\end{array}$ \\
\hline
\end{tabular}

\begin{tabular}{|c|c|c|c|c|c|c|c|}
\hline \multirow{2}{*}{ Statements } & \multicolumn{2}{|c|}{ Often } & \multicolumn{2}{|c|}{ Sometimes } & \multicolumn{2}{|c|}{ Never } & \multirow{2}{*}{$\begin{array}{c}\chi^{2} \text { and } p \\
\text { values }\end{array}$} \\
\hline & $\mathbf{M}$ & $\mathbf{F}$ & $\mathbf{M}$ & $\mathbf{F}$ & $\mathbf{M}$ & $\mathbf{F}$ & \\
\hline Praises & 50.00 & 42.67 & 47.33 & 52.00 & 2.67 & 5.33 & $\begin{array}{l}\chi^{2}=2.537 \\
p=.469\end{array}$ \\
\hline $\begin{array}{l}\text { Serves as an example to } \\
\text { others }\end{array}$ & 35.33 & 23.33 & 51.33 & 53.33 & 13.33 & 23.33 & $\begin{array}{l}\chi^{2}=7.830 \\
p=.020\end{array}$ \\
\hline Does not pay attention & 10.67 & 8.67 & 32.00 & 27.33 & 57.33 & 64.00 & $\begin{array}{l}\chi^{2}=1.410 \\
p=.494\end{array}$ \\
\hline
\end{tabular}

Table 3. Percentage distribution of the statement "You are performing an exercise well, the PE teacher..."

\begin{tabular}{|c|c|c|c|c|c|c|c|}
\hline \multirow{2}{*}{ Statements } & \multicolumn{2}{|c|}{ Often } & \multicolumn{2}{|c|}{ Sometimes } & \multicolumn{2}{|c|}{ Never } & \multirow{2}{*}{$\begin{array}{c}\chi^{2} \text { and } p \\
\text { values }\end{array}$} \\
\hline & $\mathbf{M}$ & $\mathbf{F}$ & $\mathbf{M}$ & $\mathbf{F}$ & $\mathbf{M}$ & $\mathbf{F}$ & \\
\hline Advises & 64.67 & 70.00 & 32.67 & 25.33 & 2.67 & 4.67 & $\begin{array}{l}\chi^{2}=3.298 \\
p=.348\end{array}$ \\
\hline Mocks & 4.00 & 5.33 & 16.00 & 8.67 & 80.00 & 86.00 & $\begin{array}{l}\chi^{2}=5.611 \\
p=.132\end{array}$ \\
\hline Shouts & 6.00 & 1.33 & 17.33 & 25.33 & 76.67 & 73.33 & $\begin{array}{l}\chi^{2}=8.248 \\
p=.041\end{array}$ \\
\hline Ridicules & 4.00 & 2.67 & 10.67 & 10.00 & 85.33 & 87.33 & $\begin{array}{l}\chi^{2}=0.467 \\
p=.792\end{array}$ \\
\hline
\end{tabular}

Table 4. Percentage distribution of the statement "When you did not succeed to perform an exercise well, your PE teacher..."

\begin{tabular}{|c|c|c|c|c|c|c|c|}
\hline \multirow{2}{*}{ Statements } & \multicolumn{2}{|c|}{ Often } & \multicolumn{2}{|c|}{ Sometimes } & \multicolumn{2}{|c|}{ Never } & \multirow{2}{*}{$\begin{array}{c}\chi^{2} \text { and } p \\
\text { values }\end{array}$} \\
\hline & M & $\mathbf{F}$ & M & $\mathbf{F}$ & M & $\mathbf{F}$ & \\
\hline Changes the task & 30.00 & 10.00 & 56.67 & 56.00 & 13.33 & 34.00 & $\begin{array}{l}\chi^{2}=29.559 \\
p=.001\end{array}$ \\
\hline Shouts & 3.33 & 1.33 & 18.67 & 31.33 & 78.00 & 67.33 & $\begin{array}{l}\chi^{2}=7.545 \\
p=.056\end{array}$ \\
\hline $\begin{array}{l}\text { Gesture and mimics show that } \\
\text { teacher will not change the task }\end{array}$ & 7.33 & 10.67 & 26.00 & 38.00 & 66.67 & 51.33 & $\begin{array}{l}\chi^{2}=7.290 \\
p=.026\end{array}$ \\
\hline Does not pay attention & 6.67 & 7.33 & 27.33 & 33.33 & 66.00 & 59.33 & $\begin{array}{l}\chi^{2}=3.130 \\
p=.372\end{array}$ \\
\hline
\end{tabular}

Table 5. Percentage distribution of the statement "Your PE teacher gives you a task. You contradict defending your wishes, your PE teacher..." 
$(97.3 \%)$ and female subjects $(10.7 \%)$ pointed out that the gesture and mimics of the teacher showed their inclination not to change the task. The statistically significant difference was determined in the responses with respect to gender $(p<.05)$.

\section{DISCUSSION}

Our hypothesis that attitudes of 15-16-year-old pupils with a sufficient activity level towards the physical education teacher and their behaviour will differ with respect to gender has been partly proved because the response of boys appeared to be better only in a few aspects: fewer boys than girls stated that they did not like when the teacher did not communicate with the pupils, when they lacked dedication and when they were not objective to pupils.

Our research results coincide with the data of other researchers (Blauzdys \& Bagdoniene, 2007; Fominienè et al., 2006; Galkienè, 2011; Maciulevičienè, 2014; Van den Berghe et al., 2014), showing that the pupils' attitude towards the physical education teacher highly depends on the teacher's ability to communicate, be creative and their effort in behaviour with pupils during lessons. Studies by other researchers (Bernstein et al., 2011; McDavid et al., 2014; Van den Berghe et al., 2014) have revealed that the main sources for positive approach to physical education are pupils' communication with the teacher, knowledge gained during physical education classes, the teacher's ability to engage students and satisfaction of pupils' needs. These facts were confirmed by our research results.

Teacher's morale, good will directly influence pupils' mood, work capacity, attitude to the lesson's content. Only friendly and sincere relationship can create an elevated mood that promotes efficiency, increases satisfaction with the teacher (Atencio et al., 2012). Maciulevičiene (2014) indicates that pupils like when the physical education teacher speaks calmly, vividly, expressively and correctly. Our study also found that pupils really enjoyed when the physical education teacher was calm in the classroom, took pupils' wishes into account.

Pupils are being influenced not only by the organization of teaching process, but also by the relationships between teachers and pupils. It was found that the most important trait of teachers was communication. By communicating teachers and pupils can show respect to each other, express thoughts, find common solutions, identify needs and express themselves. Therefore, the communication problem of the teacher and the pupil remains relevant (Rutkauskaitė \& Januseviciute, 2015). Teacher's duty is to develop honest members of society, moreover, the physical education teacher has another important task - to educate people leading physically active and healthy lifestyles (Galkienè, 2011; McDavid et al., 2014; Rutkauskaitė \& Januseviciute, 2015).

Rutkauskaitė and Januseviciute's (2015) study revealed that both boys and girls distinguished teacher's ability to understand as the most dominant trait. Pupils usually described their teacher as understanding, helpful, not indifferent and leading; pupils thought that their teacher was patient, friendly, had a sense of humour and understood jokes, worked with confidence, spoke with enthusiasm, was a good leader. Our research results partially confirmed these statements.

The teacher has the most crucial impact on the emotional atmosphere during physical education classes. During the lessons the teacher should avoid dictatorship, autocratic command, the pupil's personality suppression. Positive characteristics of learners, gains and optimistic points of view, beliefs in pupils should be taken into account. When the teacher, conducting the lesson, highlights positive things most pupils justify the confidence, and emotional atmosphere improves (Galkienè, 2011; Maciulevičienè, 2014).

In summary, common trends can be observed in much of the research by scientists and this article: pupils favour an intelligent, calm, creative, as well as teaching and willing to communicate physical education teacher, pupils seek their well-meaning advice. We believe that for the physical education teacher it is essential to know the wishes, needs, abilities, inclinations, character and temper of pupils as well as strive to fulfil their professional skills in developing fullyfledged members of the society.

\section{CONCLUSION}

Both boys and girls indicated knowledge of the subject, friendliness, communication with the group, taking into account pupils' opinions as the most appreciated characteristics of physical education teacher. Both genders considered that the most unfavourable teacher characteristics were insisting on meeting physical standards, non-involvement in physical activities together with pupils in the classroom and disregarding pupils' needs and wishes. More girls than boys $(p<.05)$ did not favour teacher's non-communication with pupils, lack of dedication and making offensive comments. 


\section{REFERENCES}

Atencio, M., Jess, M., \& Dewar, K. (2012). It is a case of changing your thought processes, the way you actually teach: Implementing a complex professional learning agenda in Scottish physical education. Physical Education and Sport Pedagogy, 17(2), 127-144. http://dx.doi.org/10.1080/174089 89.2011.565469

Bernstein, E., Phillips, S. R., \& Silverman, S. (2011). Attitudes and perceptions of middle school students toward competitive activities in physical education. Journal of Teaching in Physical Education, 30(1), 69-83. https://doi.org/10.1123/jtpe.30.1.69

Blauzdys, V., \& Bagdonienè, L. (2007). Mokiniu teigiamo požiūrio i kūno kultūra kaip mokymosi dalyka ugdymas, didinant jo prasminguma. Vilnius: Vilniaus pedagoginis universitetas.

Blauzdys, V., \& Vilkas, A. (2007). Kūno kultūros žinių poveikis gimnazijos mokiniu fiziniam parengtumui. Ugdymas. Kūno kultūra. Sportas, 1(64), 10-15.

Emeljanovas, A., \& Trinkūnienè, L. (2011). Mokinių požiūris i pažangos ir pasiekimų vertinimą kūno kultūros pamokose. Filosofija. Sociologija, 22(4), 466-475.

Fominienè, V., Kardelienè, L., \& Kardelis, K. (2006). Kūno kultūros mokytojų nuostata dèl komunikacijos kaip mokinių požiūrio ị kūno kultūros ugdymąsi determinantè. Ugdymas. Kūno kultūra. Sportas, 4(63), 42-48.

Freire, E. S., \& Miranda, M. L. (2014). The production of knowledge about the building of values in physical education at school: Methods, methodology and epistemology. Physical Education and Sport Pedagogy, 1, 35-47.

Galkienè, A. (2011). Šiuolaikinio mokytojo vaizdinys: mokinių požiūris. Pedagogika, 101, 82-90.

Hardman, K. (2008). Physical education in schools: A global perspective. Kinesiology, 40(1), 5-28.

Jaakkola, T., \& Washington, T. (2013). The relationship between fundamental movement skills and self-reported physical activity during Finnish junior high school. Physical Education and Sport Pedagogy, 5, 492-505. doi: 10.1080/17408989.2012.690386

Juškelienė, V., Poteliūnienè, S., Gudžinskienė, V., \& Blauzdys, V. (2010). Lietuvos kūno kultūros mokytojų sveikatos ug- dymo kompetencija stiprinti ugdytinių sveikatą. Sporto mokslas, 4(62), 53-59.

Kardelienè, L., Trinkūnienè, L., Kardelis, K., \& Masiliauskas, D. (2013). Kūno kultūros mokytojo nuomonè apie ugdytinių asmenines savybes kaip pedagoginès sąveikos prielaidą. Pedagogika, 109, 134-140.

Maciulevičienė, E. (2014). Kūno kultūros mokytojų ir aukštesnių klasių mokinių subjektyvi nuomonè apie šiuolaikinès kūno kultūros pamokos realijas. Sportini darbinguma lemiantys veiksniai (VII) (pp. 236-243). [Elektroninis išteklius]: mokslinių straipsnių rinkinys. Kaunas: LSU.

McDavid, L., Cox, A. E., \& McDonough, M. H. (2014). Need fulfilment and motivation in physical education predict trajectories of change in leisure-time physical activity in early adolescence. Psychology of Sport and Exercise, 15, 471-480. http://dx.doi.org/10.1016/j.psychsport.2014.04.006

Petrylaite, E., \& Emeljanovas, A. (2012). 5-8 klasių mokinių maloniam dalyvavimui ịtaką darantys veiksniai per kūno kultūros pamoką. Sporto mokslas, 3(69), 63-69.

Poteliūnienè, S., Blauzdys, V., \& Juškelienè, V. (2012). Lietuvos kūno kultūros mokytojų pasirengimas taikyti naujas mokinių fizinio ugdymo idejjas. Pedagogika, 105, 94-101.

Rutkauskaitè, R., \& Januševičiūtè, S. (2015). Mokinių fizinio aktyvumo ir mokymosi pasiekimų sąsajos su mokinių bei mokytojų bendravimo ir bendradarbiavimo ypatumais per kūno kultūros pamokas. Sporto mokslas, 1(79), 33-39.

Trinkūnienè, L., \& Kardelienè, L. (2013). Occupational difficulties at work of physical education teachers. Ugdymas. Kūno kultūra. Sportas, 1(88), 88-96.

Trinkūnienè, L. (2015). Kūno kultūros mokytojų požiūris ị savo darbą kaip profesinès pozicijos prielaidą. Pedagogika, 118(2), 145-158.

Van den Berghe, L., Soenens, B., Aelterman, N., Cardon, G., Tallir, I. B., \& Haerens, L. (2014). Within-person profiles of teachers' motivation to teach: Associations with need satisfaction at work, need-supportive teaching, and burnout. Psychology of Sport and Exercise, 15, 407-417. doi: 10.1016/j. psychsport.2014.04.001
Received on January 27, 2017 Accepted on March 09, 2017
Coresponding autor Vida Ivaškienè

Lithuanian Sports University Sporto str. 6, LT-44221 Kaunas Lithuania

Tel. +370 69957373

E-mail: vida.ivaskiene@1su.lt 